\title{
Productivity of aspen stands with and without a spruce understory in Alberta's boreal mixedwood forests
}

\author{
by Daniel M. MacPherson ${ }^{1}$, Victor J. Lieffers ${ }^{1,2}$ and Peter V. Blenis ${ }^{1}$
}

In northeastern Alberta, the current biomass and periodic annual biomass increment (PAI) was measured in 29 stands of maturing aspen (Populus tremuloides)-white spruce (Picea glauca), aged 48 to 105 years. Plots in pure aspen were paired with nearby plots of aspen growing on a similar landform but with a spruce understory. Biomass was estimated by diameter at breast height and allometric equations. Totalled over both species, there was $10.5 \%$ greater PAI and $10.0 \%$ greater biomass in the mixed plots than in the pure aspen plots. Pure aspen plots, however, had $12.9 \%$ greater aspen biomass and $25.2 \%$ greater aspen PAI than the aspen component of mixed plots. The apparent decline in productivity of aspen in the mixed stands, however, could not be related to the variation in spruce abundance in these mixed stands.

\section{Key words: mixed wood management, understory, spruce boreal mixed wood}

Dans le nord est de l'Alberta, la biomasse actuelle et l'accroissement périodique annuel de la biomasse (APA) ont été mesurés dans 29 peuplements de tremble (Populus tremuloides) et d'épinette blanche (Picea glauca), à maturité, âgés de 48 à 105 ans. Les parcelles dans les tremblaies pures ont été comparées à des parcelles de tremble croissant à proximité dans des conditions semblables mais avec un sous-étage d'épinette. La biomasse a été estimée selon le diamètre à hauteur de poitrine et des équations allométriques. Au total des deux espèces, on a obtenu un APA $12,5 \%$ plus grand et $10,0 \%$ de biomasse de plus dans les parcelles de peuplements mélangés que dans les parcelles des tremblaies pures. Les parcelles de tremblaies pures, cependant, atteignaient une biomasse de tremble supérieure de $12,9 \%$ et un APA pour les trembles supérieur de $25,2 \%$ par rapport à la composante de tremble des parcelles de peuplements mélangés. Le déclin apparent de la productivité du tremble dans les peuplements mélangés, cependant, ne pouvait pas être relié à la variation en abondance de l'épinette dans ces peuplements mélangés.

\section{Introduction}

Boreal mixedwood forests of trembling aspen (Populus tremuloides Michx.) and white spruce (Picea glauca (Moench) Voss) are common in Canada. Following disturbance these stands are initially dominated by aspen, with the timing and amount of white spruce recruitment in the understory varying with spruce seed source and seedbed conditions (Lieffers

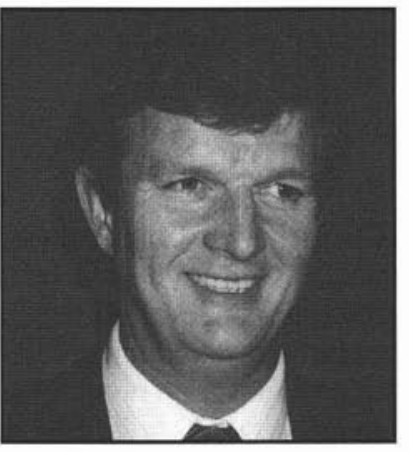

Daniel M. MacPherson et al. 1996). Once established,

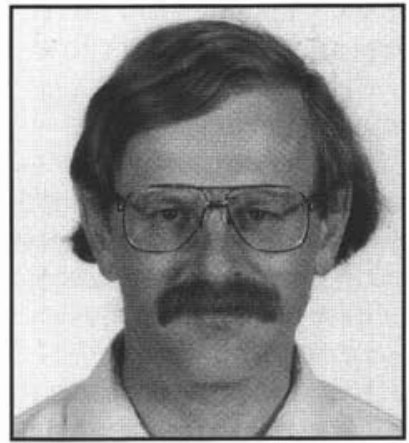

Victor J. Lieffers

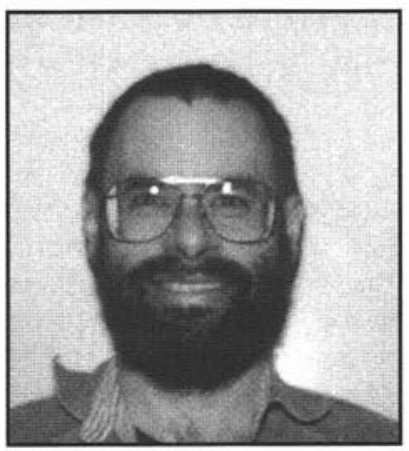

Peter V. Blenis the spruce will eventually overtop and dominate the aspen. In many jurisdictions across Canada there have been efforts to "unmix the mixedwood" forests (F. Bunnell, University of British Columbia Centre For Applied Conservation Biology, personal communication) by managing them as single species stands of either white spruce or trembling aspen. This type of management has been costly and sometimes unsuccessful (Navratil et al. 1991). As a consequence, there is interest in mixedwood management that would allow stands to develop as mixtures of aspen and spruce. The practicality of this approach, however, is partly dependent on the ability of such stands to produce large quantities of aspen and spruce fibre.

\footnotetext{
${ }^{1}$ Department of Renewable Resources, University of Alberta, Edmonton, Alberta TG6 2H1

${ }^{2}$ Corresponding author. E-mail: victor.lieffers@ualberta.ca
}

Through the process of facilitative production or competition reduction, the average productivity of two species growing together may exceed their combined averaged productivity when they are grown apart on the same area (Vandermeer 1989). Kelty (1992) identified this process leading to increased productivity in mixtures as ecological combining ability. Mixed aspen-spruce stands may possibly be more productive than pure aspen stands because of differences in canopy structures, rooting depth, leaf phenology that reduces competition between individuals and improvements in growing conditions related to increased relative humidity and nutrient cycling when these species are grown in mixture (Man and Lieffers 1999). There have been few attempts to test whether mixedwoods are indeed more productive than single species stands except for some scenario projections using the FORECAST model (Wang et al. 1995) that suggested mixed stands carry more biomass 
than single species stands. More recently in western Canada, the Western Boreal Growth and Yield Cooperative (WESTBOGY), has established growth trials to determine aspen and spruce productivity in mixtures, but the results from this study are still decades away. For this reason, a focussed study of natural stands was undertaken to determine the productivity of pure aspen stands with and without understory spruce.

This study used a design in which pure aspen plots were paired with nearby aspen plots having understory white spruce. Based on the assumption that the only difference between the plot pairs was the understory spruce, this study was the equivalent of an additive experiment where understory spruce is added to aspen. Kelty (1989) used a similar approach to demonstrate productivity of eastern hardwoods was similar with and without understory eastern hemlock (Tsuga canadensis).

The overall objective of this study was to compare the productivity of pure aspen plots with that of aspen plots having a spruce understory. The specific hypotheses tested were:

1. Total (aspen plus spruce) productivity in the mixed plots exceeded total productivity in the pure aspen plots.

2. Aspen productivity in the mixed plots was equal to aspen productivity in the pure aspen plots.

3. In the event that hypothesis 2 was rejected, then the difference in aspen productivity between pure aspen and mixed plots would be positively correlated with the amount of spruce in the mixed plots.

\section{Methods}

A total of 29 stands were selected from trembling aspen stands in the boreal forest in northeastern Alberta: Athabasca (6), Calling Lake (7), Wandering River (8) and north of Lac La Biche lake (8). All stands were in either the Central or Dry Mixedwood Natural Subregions (Beckingham and Archibald 1996).

\section{Ecological site and stand selection criteria}

Stands were selected to meet several criteria. The overstory aspen was healthy, uniform, even aged, at least 40 years old, and with greater than $75 \%$ canopy closure. Each stand had less than $5 \%$ slope and was at least $500 \mathrm{~m}$ from any other sampled stand. All stands belonged to one of three plant community types within the ecosites: d1.2 (Aw/saskatoon-pin cherry), d1.3 (Aw-beaked hazelnut) and d2.2 (Aw-Sw beaked hazelnut) (Beckingham and Archibald 1996). These were the most abundant ecosites within the natural subregions. All of these plant ecosites had a similar component of saskatoon (Amelanchier alnifolia) as an indicator species, allowing efficient site identification.

Further selection criteria were applied in the field. The stands had to have a) areas with healthy spruce understory near areas with no spruce understory, b) uniform aspen stem distribution without large canopy gaps, c) no evidence of grazing, harvesting, or mechanical disturbances and d) no natural disturbances (such as wind throw), for the past five years.

\section{Plot location selection}

In each of the 29 stands, six $83.3-\mathrm{m}^{2}$ fixed area circular plots were established, three in the pure aspen (pure aspen plots), and three in the mixed portion (mixed plots). The first plot established was a mixed plot. A paired plot was then established in pure aspen, $30 \mathrm{~m}$ away. This process was repeated until all six plots had been located. In mixed plots with a high density of spruce, plots were selected to have a 10 -m buffer with similar spruce density.

\section{Treatment layout and measurement}

The diameter at breast height $(1.3 \mathrm{~m}, \mathrm{DBH})$ was recorded on all trees in all plots. In the pure aspen plots, four sample trees were chosen, covering the range of diameters. The heights of these trees were determined with a clinometer and increment cores were taken from two directions, at right angles, on the bole of each sample tree. The increment cores were shaved with a razor blade, chalk dust was applied to the cut surface and rings were counted using a dissecting microscope. The radial increment for the last five years was measured with a Parker micrometer and the increments for the two cores from each tree were averaged. Ageing of all plots was not possible due to stem rot. However, after estimating these missing rings, maximum aspen ages in the six plots per stand varied by less than five years. The same procedure was followed in the mixed plots, sampling four trees each of aspen and spruce.

To determine the relationship between spruce crown characteristics and their DBH and height, 49 understory spruce crowns were measured in 12 randomly selected stands. DBH, total tree height, crown radius and height to live crown were sampled on a maximum of five trees per stand.

\section{Data Compilation}

Determination of diameter increment followed the double sampling procedure outlined in Lieffers and Campbell (1983). Simple linear regression was used to predict diameter increment, separately, in each stand over the last five years as a function of current diameter. Eighty-seven separate equations were developed for aspen in the pure plots, aspen in mixed plots and spruce in mixed plots.

The development of a height to diameter relationship was required before biomass could be estimated. The height-diameter model used was from Huang et al. (1994):

$$
\mathrm{H}=1.3+\mathrm{a}\left(1-\mathrm{e}^{-\mathrm{bDBH}}\right)^{\mathrm{c}},
$$

Coefficients $\mathrm{a}, \mathrm{b}$, and $\mathrm{c}$ were fitted using non-linear regression (PROC NLIN of SAS (1995)). The data from the 29 stands were combined to develop three equations, one each for pure aspen, mixed aspen and understory spruce. Because there was considerable overlap of the $95 \%$ confidence intervals for the $\mathrm{a}, \mathrm{b}$, and $\mathrm{c}$ coefficients for pure and mixed aspen, those data were combined and new values of a, b and c calculated. The final equation for predicting aspen height $(n=690)$ was:

$$
\mathrm{H}=1.3+25.248095 *(1-\exp (-0.090486 * \mathrm{DBH}))^{* 1.2975988}
$$

and the equation for spruce $(n=342)$ was:

$$
\mathrm{H}=1.3+52.642950 *(1-\exp (-0.017904 * \mathrm{DBH}))^{* 1.0608138}
$$

The present and past biomass of all trees in all plots was estimated using the direct measurements of $\mathrm{DBH}$ and the modelled increments of diameter and height. The current height of each tree in each plot was calculated on the basis of the height to diameter relationship. The diameter five years previous was estimated by subtracting the radial increment (calculated on the basis of the increment to diameter relationship) from the current diam- 


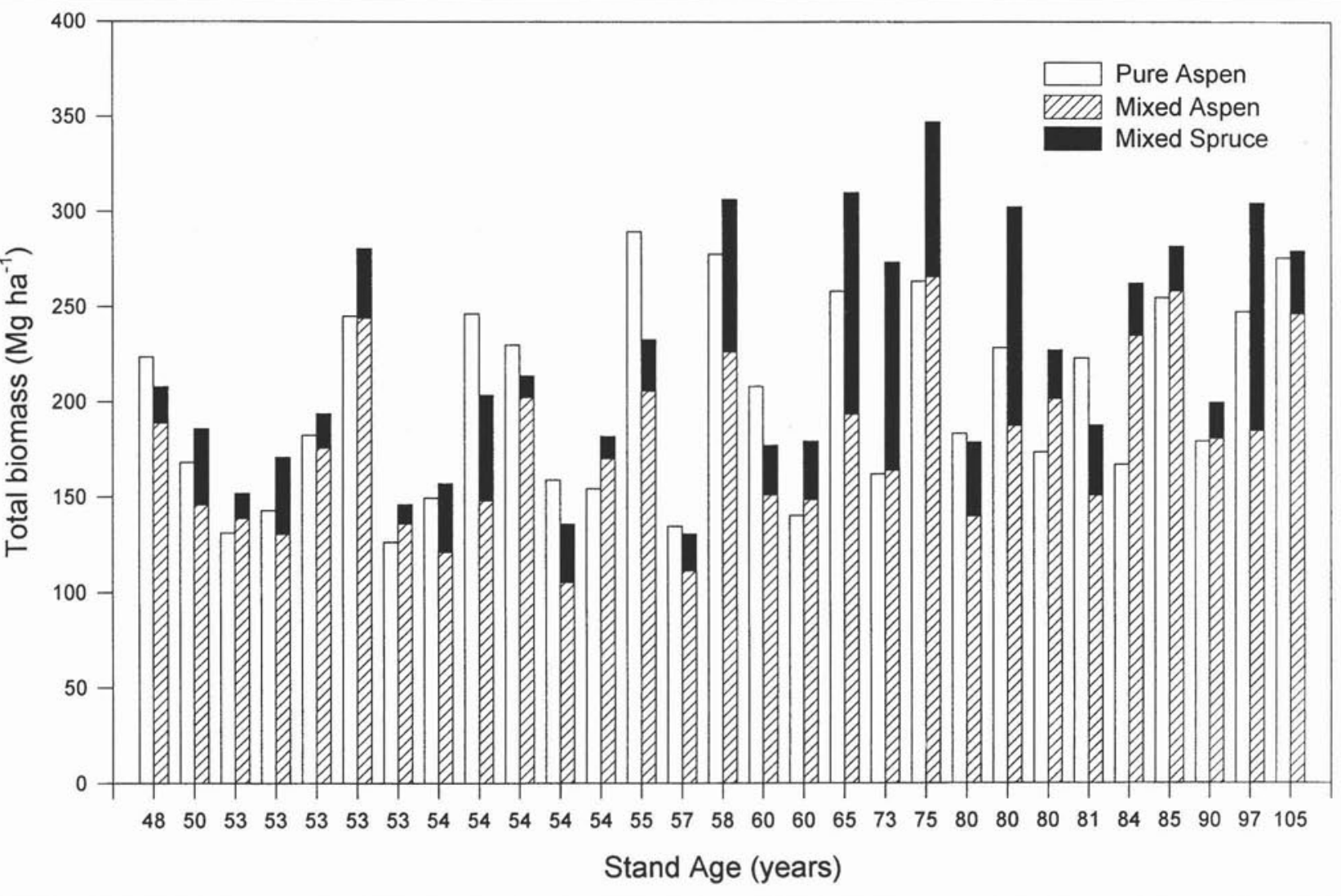

Fig. 1. Total biomass of pure and mixed (aspen and spruce) stands. The comparison of 29 paired aspen stands is arranged from youngest to O

eter. Once current and past heights and diameters were deterFined, the current and past biomass of each tree was calculated. The equation used for aspen, which had been developed for the same general region, (Singh 1982) was as follows:

$$
\text { Biomass }(\mathrm{kg})=0.34961+0.01916(\mathrm{DBH})^{2} \mathrm{H}
$$

The equation for spruce was:

$$
\text { Biomass }(\mathrm{kg})=6.09159+0.01499(\mathrm{DBH})^{2} \mathrm{H}
$$

These equations estimated total above ground biomass without foliage. Biomass for each plot was calculated by summing the values of the individual trees. By subtracting the past plot biomass from the present plot biomass, a five-year biomass increment was determined. This five-year increment was then divided by 5 to determine a periodic annual increment (PAI). The totals of the three $83.3-\mathrm{m}^{2}$ plots were scaled up to a hectare basis by multiplying by 40 .

\section{Statistical Analysis}

Two methods were used to compare productivity between pure and mixed stands: paired t-tests to determine if means were different and exact chi-square tests for frequency analysis. Regression analysis was used to determine if the reduction in aspen productivity in the mixed plots increased with increasing spruce competition. The following variables were used as indicators of spruce competition: total stand biomass, periodic annual increment, spruce crown area, spruce crown volume, and spruce basal area. The best one-, two-, three-, and four-variable models were examined.

\section{Results}

Among all the stands, aspen ages ranged from 48 to 105 years at $1.3 \mathrm{~m}$ height. Dominant spruce understory ages varied from four to 64 years at breast height. The average age difference between dominant understory spruce and overstory aspen was 22.9 years at breast height. No age-biomass relationship (Fig. 1) or age-PAI relationship (Fig. 2) was evident. This lack of an age-biomass relationship in aspen suggests that aspen stand productivity reached its maximum at an early age.

Aspen density was similar in pure and mixed plots, i.e., for the 29 stands, 1458 stems/ha in the pure plots and 1462 in the mixed. At the extremes across the 29 stands, however, there was up to a $41 \%$ difference in the aspen density between the pure and mixed components of the stands. The mean density of spruce understories was 1056 stems/ha and was highly variable, ranging from 200 to $2920 \mathrm{stems} / \mathrm{ha}$.

Mixed plots carried $23.2 \%$ more basal area of aspen and spruce combined than did pure aspen plots $(\mathrm{P}<0.0001),\left(47.3 \mathrm{~m}^{2} / \mathrm{ha}\right.$ versus $38.4 \mathrm{~m}^{2} / \mathrm{ha}$ for pure aspen plots). In contrast, there was $11.0 \%$ greater basal area of aspen in the pure aspen plots than in the mixed plots $(\mathrm{P}=0.0028),\left(38.4 \mathrm{~m}^{2} /\right.$ ha versus $34.6 \mathrm{~m}^{2} / \mathrm{ha}$ for the mixed plots). On average, spruce represented $26.9 \%$ of the basal area of mixed plots. Average height to diameter ratio for the spruce across all plots was 84.3 (height and diameter in the same units). 


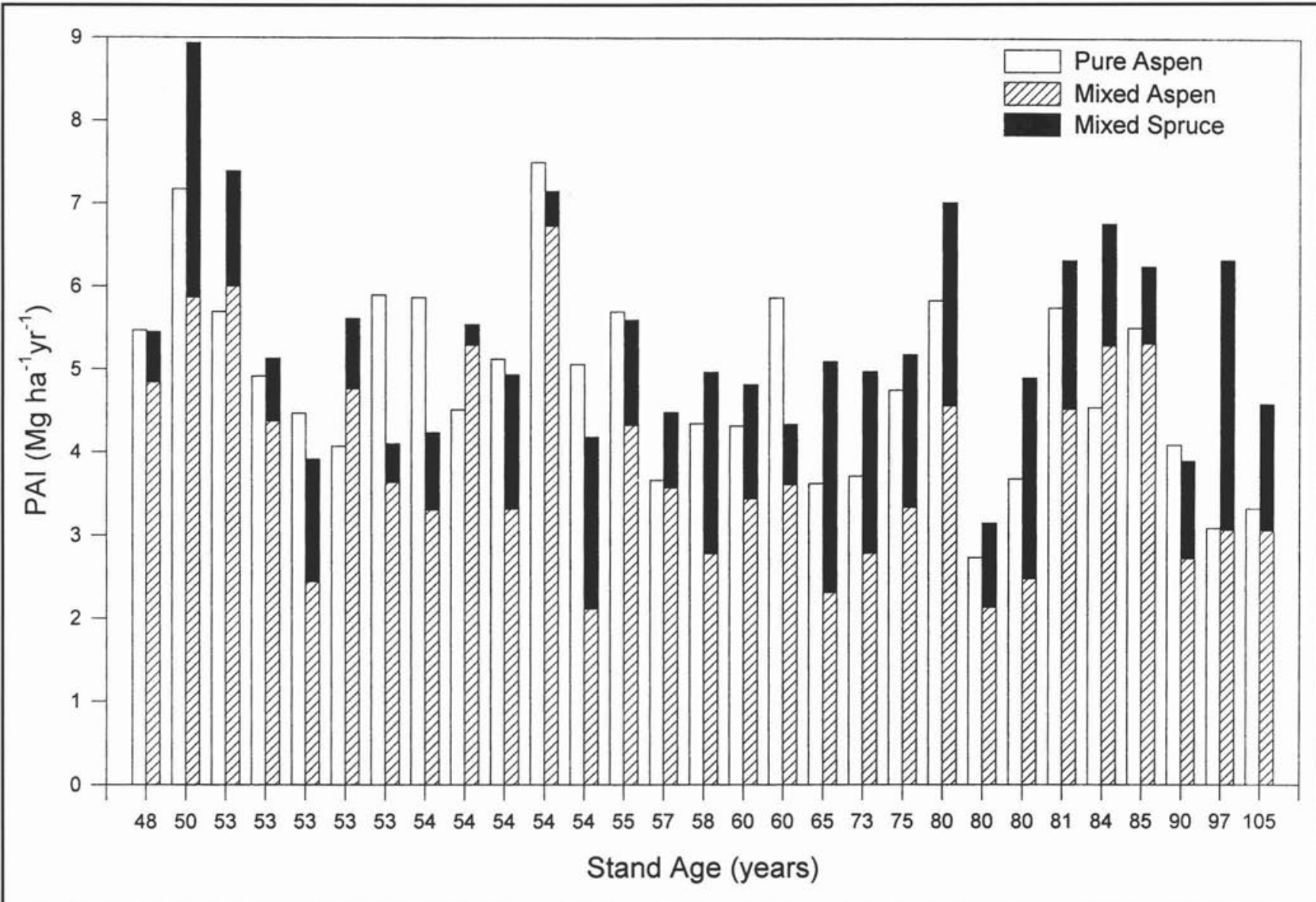

Fig. 2. Periodic annual increment (five-year) of pure and mixed (aspen and spruce) stands. A comparison of 29 paired aspen stands are arranged from youngest to oldest to demonstrate that no age-PAI relationship existed.

Mean stand biomass for aspen in the mixed plots was 178 $\mathrm{Mg} / \mathrm{ha}$ compared to $201 \mathrm{Mg} /$ ha for aspen in the pure aspen plots. This difference of $23.0 \mathrm{Mg} /$ ha was significant at $\mathrm{P}=0.011$, had a $95 \%$ confidence interval $(\mathrm{CI})$ of $\pm 13.9 \mathrm{Mg} / \mathrm{ha}$ and represented $12.9 \%$ greater aspen productivity in the pure aspen plots. Nineteen stands had more aspen biomass in the pure aspen plots than in the mixed plots, whereas 10 mixed plots had more aspen biomass than the pure plots $(\mathrm{P}=0.068)$. Mean biomass of spruce in the mixed plots was $43 \mathrm{Mg} / \mathrm{ha}$, and ranged from 10 to 119 $\mathrm{Mg} / \mathrm{ha}$. When this spruce biomass was added to aspen biomass, the mixed plots had $10.0 \%(20.1 \mathrm{Mg} / \mathrm{ha}, 95 \%$ C.I. \pm 15.6$)$ more total biomass than pure aspen plots $(P=0.0067)$. Twenty of the stands had greater total biomass in the mixed than in the pure aspen plots, compared to only nine stands with greater total biomass in the pure aspen plots $(\mathrm{P}=0.030)$.

The reduction in aspen biomass in the mixed plots, relative to the pure aspen plots, was weakly correlated with spruce PAI $\left(\mathrm{P}=0.045, \mathrm{R}^{2}=0.141\right)$ (Fig. 3), spruce basal area $(\mathrm{P}=0.053$, $\left.R^{2}=0.131\right)$ and spruce biomass $\left(P=0.081, R^{2}=0.108\right)$. The other indicators of spruce competition, spruce crown area and spruce crown volume, were not significantly associated with the reduction in aspen biomass in the mixed plots. None of the models with two or more variables was better than the single variable models.

\section{Periodic annual increment (PAI)}

Mean stand PAI for aspen in the mixed plots was 3.87 $\mathrm{Mg} / \mathrm{ha}$ compared to $4.84 \mathrm{Mg} / \mathrm{ha}$ for the aspen of the pure plots. Thus there was $25.2 \%(0.97 \mathrm{Mg} /$ ha/year, $95 \%$ C.I. \pm 0.4$)$ greater PAI for aspen in the pure aspen plots than in the mixed plots $(\mathrm{P}<0.001)$. Twenty-five of the stands had greater aspen PAI in the pure aspen plots than in the mixed plots, compared to only four stands with greater aspen PAI in the mixed plots $(\mathrm{P}<0.001)$. Mean PAI of the spruce in the mixed stands was $1.49 \mathrm{Mg} / \mathrm{ha}$. When spruce was added to aspen PAI, the mixed plots had $10.5 \%(0.51 \mathrm{Mg} / \mathrm{ha} /$ year, $95 \%$ C.I. \pm 0.4$)$ more PAI than pure aspen plots $(\mathrm{P}=0.0118)$. Nineteen of the stands had greater total PAI in mixed plots, compared to ten stands having greater total PAI in the pure plots $(\mathrm{P}=0.0680)$.

The reduction in aspen PAI in the mixed plots, relative to the pure aspen plots, was not significantly correlated with spruce basal area $\left(R^{2}=0.041\right)$, spruce biomass $\left(R^{2}=0.021\right)$, spruce $\operatorname{PAI}\left(R^{2}=0.027\right)$, spruce crown area $\left(R^{2}=0.024\right)$ or spruce crown volume $\left(R^{2}=0.033\right)$.

\section{Discussion}

Mixed plots carried $10.0 \%$ more total biomass (aspen + spruce) than pure aspen plots. This finding is consistent with the theory that mixed stands are more productive than monocul- 


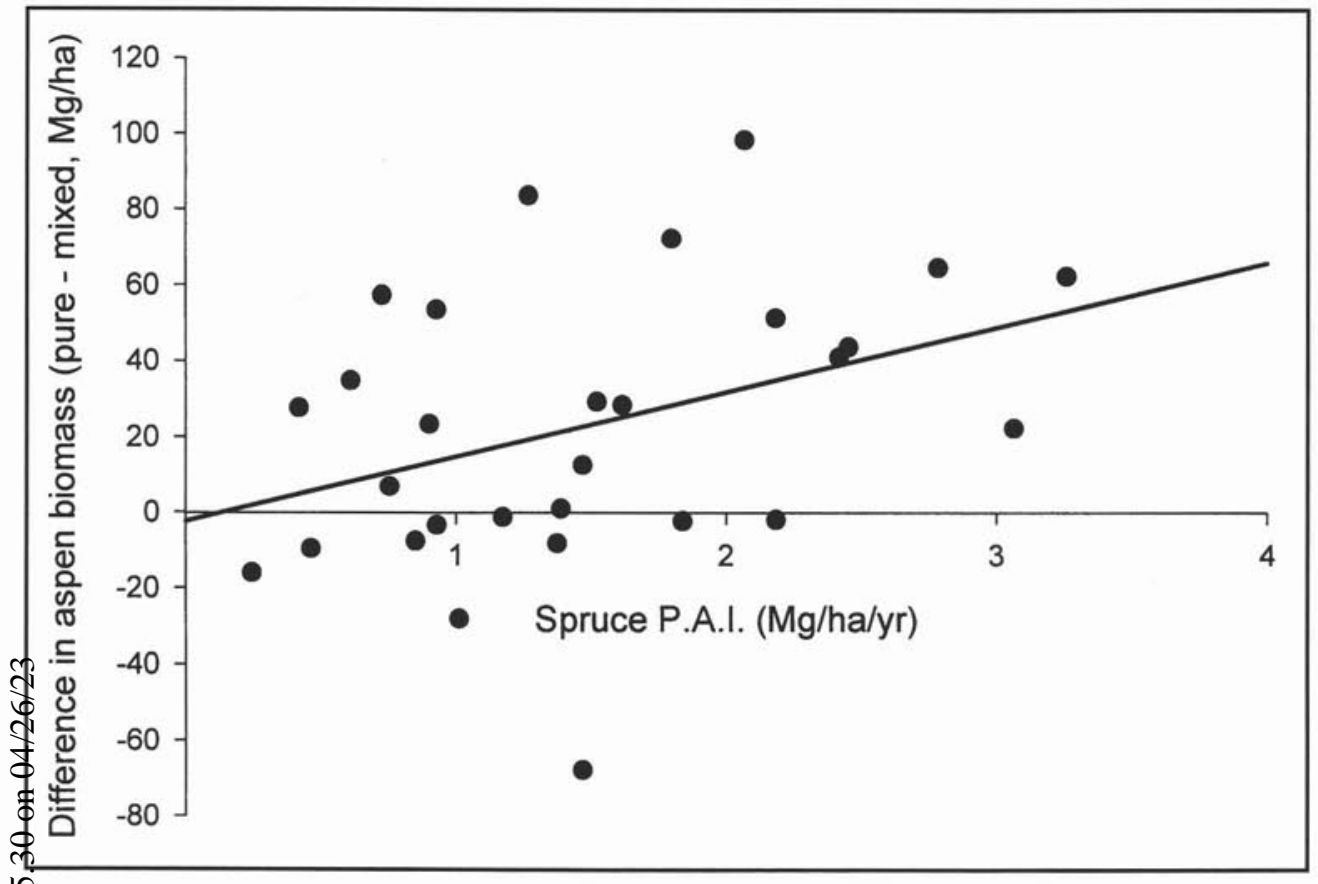

Fig. 3. Difference in aspen biomass (biomass from pure aspen stand minus biomass of aspen in mixed stand) versus understory white spruce PAI from the mixed stand. $\mathrm{D}=16.528 * \mathrm{~S}-1.911, \mathrm{R}^{2}=0.141$, $\mathrm{P}=0.045$.

$m$

Jures (Vandermeer 1989) and with the observation that stands oith shade-intolerant hardwoods growing over shade-tolerant Sonifers were more productive than shade intolerant hardTwods alone (Kelty 1989). Similarly, total PAI in the mixed कृष्ठts was $10.5 \%$ greater than pure aspen plot PAI. The greater foreal biomass and total PAI in the mixed plots supports the first Fupothesis, that mixed stands of aspen and white spruce would fog more productive than stands of pure aspen. Given that the finny of the mixed stands had very low stocking of understoIforspruce, the productivity differences would likely have been F⿳⺈⿴囗十 ater if understory spruce stocking had been consistently high. Comparison of the productivity of aspen alone showed that the pure aspen plots carried $12.9 \%$ more aspen biomass than Amixed plots. Pure aspen plots also had $25.2 \%$ more aspen PAI Jhan mixed plots. This was despite the fact that there was no Zुlifference in average stem density between pure and mixed plots. These results indicate that aspen productivity in mixed plots was less than in pure aspen plots, disproving the second fyypothesis that aspen productivity in the mixed plots would be Fqual to aspen productivity in the pure aspen plots. The larger difference in current productivity (five-year-based PAI) ff $25.2 \%$, compared to the $12.9 \%$ difference in cumulative aspen biomass suggests that the productivity difference is a more recent phenomenon.

The third hypothesis, that the difference in aspen productivity between pure and mixed plots would be positively correlated with the amount of spruce in the mixed plots was not supported by the PAI data. There was no significant decline in the aspen $\mathrm{PAI}$ as the spruce component increased, even though there was a wide range in spruce biomass in the mixed plots (10 to 119 $\mathrm{Mg} / \mathrm{ha}$ ). In contrast, the hypothesis appears to be supported by the biomass data (Fig. 3). However, the correlations between aspen biomass reduction and the various indices of spruce competition were extremely weak. Furthermore, because every possible one-, two-, three- and four-variable model was examined in an attempt to detect a correlation, the P values may be underestimated. Hence, there was little evidence that the addition of a spruce understory reduced aspen productivity in mixed plots.

If there was no correlation between the reduction in aspen productivity in mixedwoods and the indicators of spruce competition, then what would account for the reduction in aspen productivity in the mixed plots? There are large differences in productivity among aspen clones (Lehn and Higginbotham 1982). More productive clones may have carried more leaf area in their juvenile state than less productive clones. Productive clones may, therefore, have transmitted insufficient light to allow any spruce to survive. This may be sufficient to account for the difference in aspen productivity between pure aspen and mixed plots, even if the spruce was currently having no adverse effect on aspen productivity.

The overall goal of this study was to examine the relative suitability of mixedwood and pure aspen management for the production of aspen and total (aspen + spruce) biomass. The most accurate way to assess production would be to plant aspen and spruce together in various combinations and maintain these densities over time. Indeed, the WESBOGY experiment (WESBOGY 1997), examining different planting densities of aspen and spruce, will eventually yield these types of data. The present study attempts to obtain answers for this problem much earlier than the experimental approach but suffers from several criticisms.

1. Kelty (1992) points out, "The spatial arrangement of trees of different species must be fine-grained (i.e., trees must be adjacent to trees of different species) in order for reduction of competition to occur." In natural stands trees have clumped or random distributions and, thus this objective was not achieved.

2. The lack of control over depth of organic substrate at the time of the stand replacing fire (Johnson 1992) may have affected productivity or spruce recruitment in the pure or mixed plots. 
3. Clonal variation of the aspen increased the variability of productivity among and within stands.

4. The 29 stands were chosen such that the plots with only aspen were as similar as possible to the aspen component of the mixed plots. However, it is not absolutely certain that there were not other differences between pure and mixed plots that simultaneously contributed to the establishment of spruce and the differences in productivity.

Although an experimental approach to evaluating mixedwood productivity would likely provide less ambiguous results than the observational approached used in our study, it will take many years for such experiments to be completed. Despite the difficulties inherent in this study, the results are useful for managers who need to make decisions in the near future. There was a clear increase in total biomass and PAI in the mixedwood plots, confirming the superior productivity of mixedwood stands. Because the surveyed stands included stands with small and/or low density spruce, it is possible that the increases of $10.5 \%$ in PAI and $10.0 \%$ in biomass may underestimate the increase that could be realized under mixedwood management. It is somewhat less certain that a well developed spruce understory can be maintained without sustaining a reduction in aspen productivity; it is possible that the spruce lead to a reduction in aspen biomass that was not detected because of the relatively small sample size and large variability in the system. Nevertheless, our data suggest that relatively large volumes of spruce (up to 119 tons/ha) might be added to aspen stands without a large reduction in aspen productivity.

\section{Acknowledgements}

We thank Vashti Thompson and Sarah Lieffers for field assistance, Simon Landhäusser, Ken Stadt and Gitte Grover for advice and Alberta Pacific Forest Industries and NCE-Sustainable Forest Management for funding.

\section{References}

Beckingham, J.D. and J.H. Archibald. 1996. Field guide to ecosites of Northern Alberta. Special Report 5. Can. For. Serv., North. For. Cent., Edmonton Alberta.
Huang, S., S.J. Titus, T.W. Lakusta and R.J. Held. 1994. Ecologically based individual tree height-diameter models for major Alberta tree species. Alberta Environmental Protection, Lands and Forest Services, Forest Management Division, Edmonton, Alberta. 27 p.

Johnson, E.A. 1992. Fire and vegetation dynamics-studies from the North American boreal forest. Cambridge Studies in Ecology. Cambridge University Press. Cambridge. 129 p.

Kelty, M.J. 1989. Productivity of New England hemlock/hardwood stands as affected by species composition and canopy structure. For. Ecol. Manage. 28 237-257.

Kelty, M.J. 1992. Comparative productivity of monocultures and mixed species stands. In M.J. Kelty, B.C. Larson and C.D. Oliver (sds.). The ecology and silviculture of mixed-species forests. pp.125-141. Kluwer Academic Publishers, Dordrecht. 287 p.

Lehn, G.A. and K.O. Higginbotham. 1982. Natural variation in merchantable stem biomass and volume among clones of Populus tremuloides Michx. Can J. For. Res. 12: 83-89.

Lieffers, V.J. and J.S. Campbell. 1984. Biomass and growth of Populus tremuloides in northeastern Alberta: estimates using hierarchy in tree size. Can J. For. Res. 14: 610-616.

Lieffers, V.J., R.B. Macmillan, D. MacPherson, K. Branter and J.D. Stewart. 1996. Semi-natural and intensive silvicultural systems for the boreal mixedwood forest. For. Chron. 72: 286-292.

Man, R. and V.J. Lieffers, 1999. Are mixtures of aspen and white spruce more productive than single species stands? For. Chron.75: 505-513.

Navratil, S., K. Branter and J. Zasada, 1991. Regeneration in the mixedwoods. In A. Shortried (ed.). Northern mixed-wood '89. Proc. Symp., Sept. 12-14, 1989, Fort St. John, B.C. pp. 32-48. Pacific Forestry Centre, Victoria, B.C. FRDA Rep. 164.

SAS. 1995. SAS/STAT user's guide, Version 6.11 edition. SAS Institute Inc. Cary NC.

Singh, T. 1982. Biomass Equations for Ten Major Tree Species of the Prairie Provinces. Nor. For. Res. Cent. Can. For. Serv., Edmonton Alberta. Info. Rep. NOR-X-242.

Vandermeer, J. 1989. The Ecology of Intercropping. pp. 15-64. Cambridge University Press. 237 p.

Wang, J.R., P. Comeau and J.P. Kimmins. 1995. Simulation of mixedwood management of aspen and white spruce in northeastern British Columbia. Water, Air and Soil Pollution 82: 171-178.

WESBOGY. 1997. Permanent sample plot data collection manual. S.J. Titus (ed.). Dept. of Renewable Resources, University of Alberta, Edmonton, AB. 32 p. 